\title{
Photochemical Studies
}

\section{XIII.* The Liquid Phase Photolysis of Quinoline $N$-Oxides Unsubstituted in the 2-Position**}

\author{
OLE B UCHARDT, PHILIP L. KUMLER*** \\ Chemical Laboratory II (General and Organic Chemistry), University of Copenhagen, \\ The H. C. Ørsted Institute, Copenhagen, Denmark \\ an d \\ CHR IST I A N L OHSE
}

The Chemical Institute, University of Odense, Odense, Denmark

The photolysis, in various solvents, of a series of quinoline $N$ oxides (I) without substituents in the 2-position, is reported. The product distribution shows a remarkable solvent dependence. In protic solvents the isomeric carbostyrils (II) are formed; in aprotic solvents carbostyril formation is decreased, and $N$-formyl-2-indolinols (III) or their open-chain tautomers (III') are produced. Minor amounts of other products were observed in most photolyses. A mechanistic rationalization of these findings is presented.

In a preliminary communication, ${ }^{2}$ we described the light-induced formation 1 of some $N$-formyl-2-indolinols (IIIa, e, o) from quinoline $N$-oxides (Ia, e, o) in ether or benzene solution ( $c f$. Ref. 3). Previously, the formation of carbostyrils (II) from type I quinoline $N$-oxides in aqueous ${ }^{4}$ and methanolic ${ }^{5}$ solution had been reported. To further investigate the light-induced reactions

\footnotetext{
* For the previous paper see Ref. 1.

** A preliminary communication of part of this work has appeared. ${ }^{2}$ The experimental details of the previous work are included in the present paper.

*** NATO Research Fellow, 1967-68. Present address: Department of Chemistry, University of Chicago, Chicago, Illinois 60 637, U.S.A.
} 


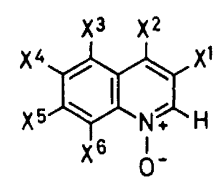

1

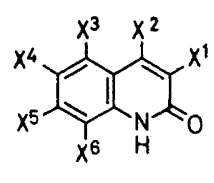

II

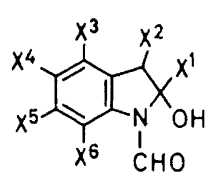

III

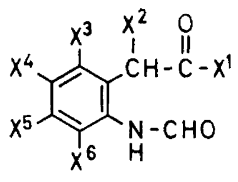

II $^{\prime}$

\begin{tabular}{|c|c|c|c|c|c|c|}
\hline & $\mathrm{X}^{1}$ & $\mathrm{X}^{2}$ & $\mathrm{X}^{3}$ & $\mathrm{X}^{4}$ & $X^{5}$ & $\mathrm{X}^{6}$ \\
\hline $\mathbf{a}$ & $\mathbf{H}$ & $\mathrm{H}$ & $\mathbf{H}$ & $\mathrm{H}$ & $\mathrm{H}$ & $\mathrm{H}$ \\
\hline $\mathrm{b}$ & $\mathrm{C}_{2} \mathrm{H}_{3}$ & $\mathrm{H}$ & $\mathrm{H}$ & $\mathrm{H}$ & $\mathrm{H}$ & $\mathrm{H}$ \\
\hline c & $\mathbf{H}$ & $\mathrm{CH}_{3}$ & $\mathrm{H}$ & $\mathrm{H}$ & $\mathrm{H}$ & $\mathrm{H}$ \\
\hline d & $\mathbf{H}$ & $\mathbf{H}$ & $\mathrm{CH}_{3}$ & $\mathrm{H}$ & $\mathbf{H}$ & $\mathrm{H}$ \\
\hline $\mathrm{e}$ & $\mathrm{H}$ & $\mathrm{H}$ & $\mathbf{H}$ & $\mathrm{CH}_{3}$ & $\mathrm{H}$ & $\mathrm{H}$ \\
\hline $\mathrm{f}$ & $\mathbf{H}$ & $\mathbf{H}$ & $\mathrm{H}$ & $\mathbf{H}$ & $\mathrm{CH}_{3}$ & $\mathrm{H}$ \\
\hline $\mathrm{g}$ & $\mathrm{H}$ & $\mathbf{H}$ & $\mathrm{H}$ & $\mathrm{H}$ & $\mathrm{H}$ & $\mathrm{CH}_{3}$ \\
\hline $\mathrm{h}$ & $\mathrm{Br}$ & $\mathbf{H}$ & $\mathrm{H}$ & $\mathrm{H}$ & $\mathbf{H}$ & $\mathrm{H}$ \\
\hline $\mathrm{i}$ & $\mathbf{H}$ & $\mathrm{Cl}$ & $\mathrm{H}$ & $\mathrm{H}$ & $\mathrm{H}$ & $\mathrm{H}$ \\
\hline $\mathrm{j}$ & $\mathbf{H}$ & $\mathrm{Br}$ & $\mathrm{H}$ & $\mathbf{H}$ & $\mathrm{H}$ & $\mathbf{H}$ \\
\hline $\mathbf{k}$ & $\mathbf{H}$ & $\mathrm{H}$ & $\mathbf{H}$ & $\mathrm{F}$ & $\mathrm{H}$ & $\mathrm{H}$ \\
\hline 1 & $\mathbf{H}$ & $\mathrm{H}$ & $\mathrm{H}$ & $\mathrm{Cl}$ & $\mathrm{H}$ & $\underline{H}$ \\
\hline $\mathbf{m}$ & $\mathrm{H}$ & $\mathbf{H}$ & $\mathrm{H}$ & $\mathrm{Br}$ & H & $\mathbf{H}$ \\
\hline $\mathbf{n}$ & $\mathbf{H}$ & $\mathbf{H}$ & $\mathrm{H}$ & $\mathrm{H}$ & $\mathrm{Cl}$ & $\mathrm{H}$ \\
\hline o & $\mathbf{H}$ & $\mathbf{H}$ & $\mathbf{H}$ & $\mathrm{OCH}_{3}$ & $\mathrm{H}$ & $\mathrm{H}$ \\
\hline p & $\mathrm{H}$ & $\mathrm{CH}_{3}$ & $\mathrm{H}$ & $\mathrm{OCH}_{3}$ & $\mathrm{H}$ & $\mathrm{H}$ \\
\hline$q$ & $\mathrm{H}$ & $\mathrm{H}$ & $\mathrm{H}$ & $\mathrm{H}$ & $\mathrm{H}$ & $\mathrm{OCH}$ \\
\hline
\end{tabular}

of type I quinoline $N$-oxides we have irradiated an extended series of these $(\mathrm{Ia}-\mathrm{q})$ in various solvents.*

* We have found acetone to be the preferred solvent for formation of benz[d][1,3]oxazepines, the presumed precursors of the $N$-formyl-2-indolinols (III) or their open-chain tautomers III', $^{\prime}$, in the photolysis of quinoline $N$-oxides. ${ }^{6}$ Therefore, we have used this aprotic solvent instead of ether or benzene in our recent studies. 


\begin{tabular}{|c|c|c|c|c|c|c|c|c|c|c|c|}
\hline 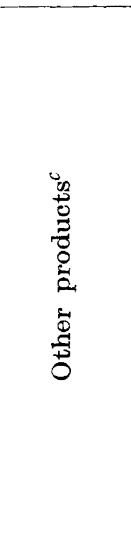 & 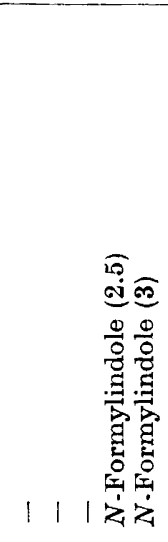 & & 1 & 10 & (3) & I & 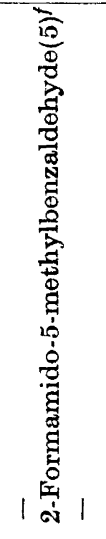 & 11 & 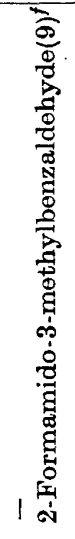 & 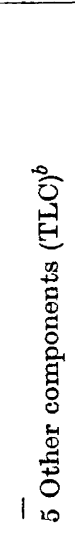 & 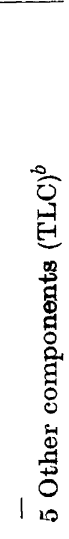 \\
\hline 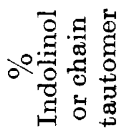 & 18117 & 10 & 1 & $1^{2}$ & i⿱ & 1 & $1 \leftrightarrow 1$ & 11 & $1 \cong$ & 11 & $1 \stackrel{\text { के }}{1}$ \\
\hline ○룜 & | $\mid \stackrel{\oplus}{\mid}$ | & 11 & 1 & 11 & 11 & 1 & 118 & 18 & 11 & 11 & 11 \\
\hline 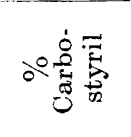 & $\sigma \circ 8 \underbrace{\circ}$ & $8=$ & 8 & 요 & 20 & $\infty$ & 요 & $\stackrel{\infty}{\infty} 1$ & $\triangle F$ & 80 & $\begin{array}{l}80 \\
0 \\
1 \\
1 \\
15 \\
10\end{array}$ \\
\hline 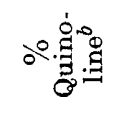 & D & 釉 & 1 & 岙 & 足 & 1 & | 兽 | & 11 & 11 & 谓足 & $i_{\infty}^{i}$ \\
\hline 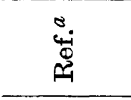 & H N & 11 & + & +1 & 100 & H & Ha 1 & +1 & +1 & 11 & 201 \\
\hline 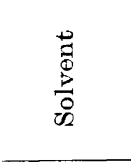 & 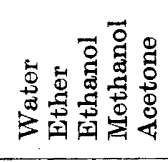 & 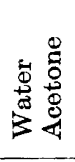 & 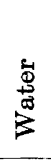 & 总 & 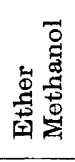 & 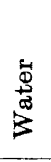 & 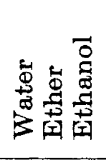 & 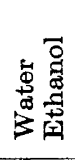 & 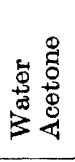 & 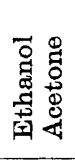 & 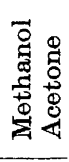 \\
\hline 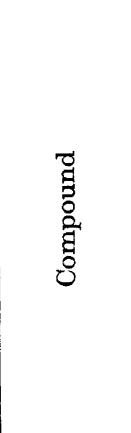 & 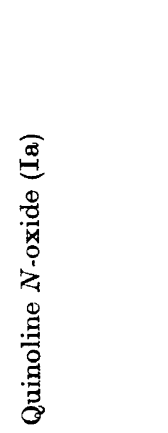 & 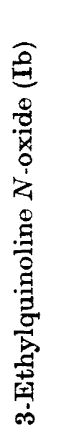 & 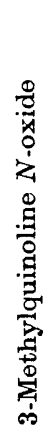 & 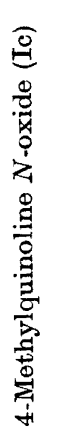 & & 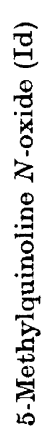 & 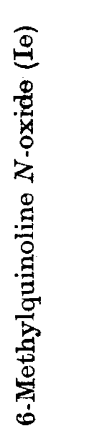 & 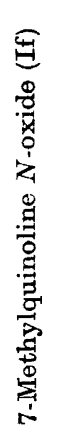 & 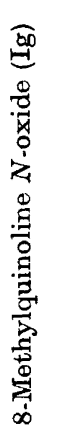 & 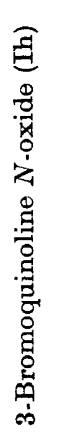 & 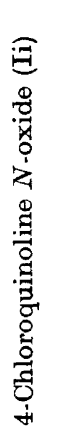 \\
\hline
\end{tabular}

Acta Chem. Scand. 23 (1969) No. 1 


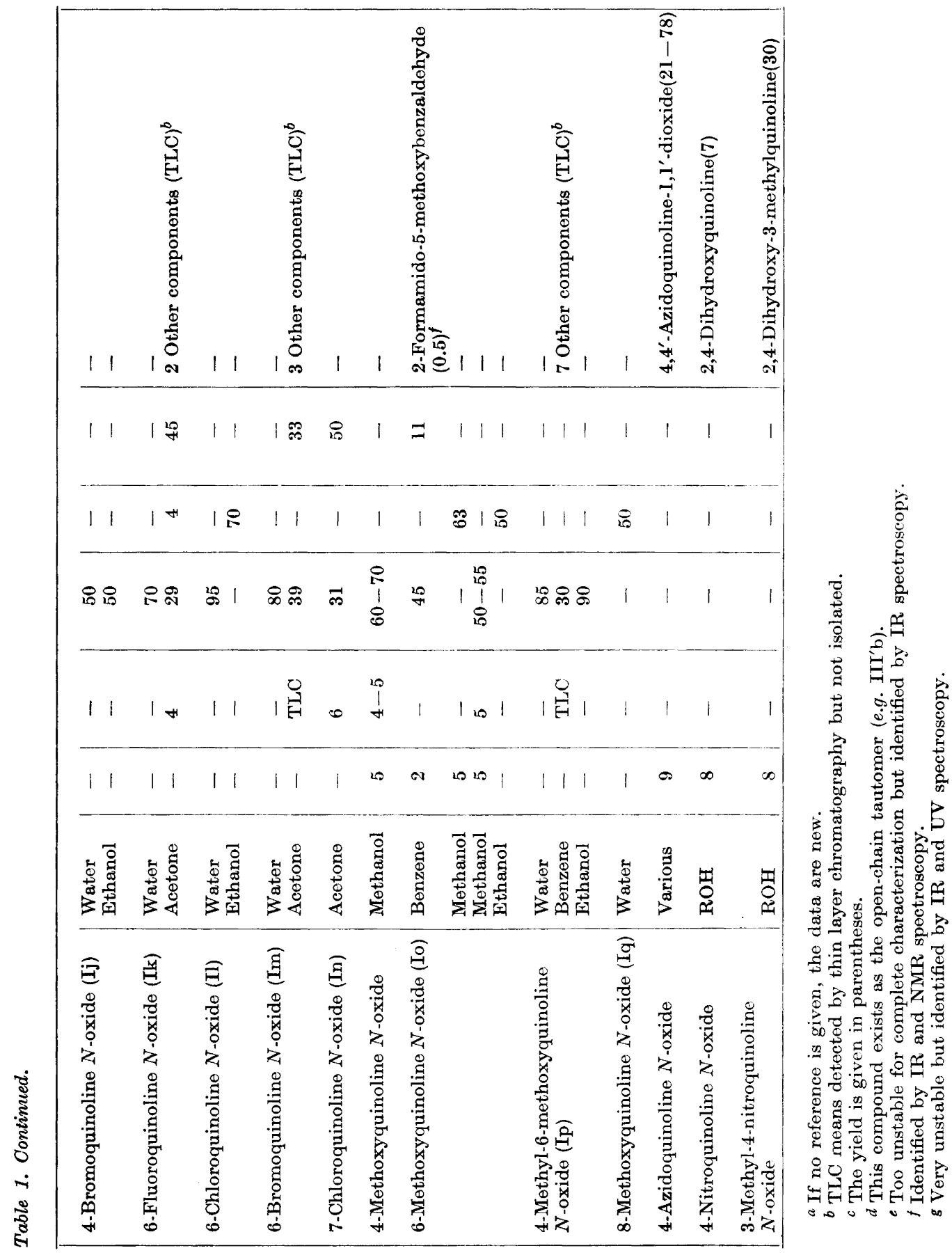

Acta Chem. Scand. 23 (1969) No. 1 


\section{IRRADIATIONS}

In each case the irradiation of quinoline $N$-oxides in aqueous solution led to the formation of carbostyrils in high yields. In some cases minor amounts of the parent quinolines and other byproducts were observed by thin layer chromatography (TLC). The results of these experiments are summarized in Table 1. If $96 \%$ ethanol was used as solvent, carbostyril formation again dominated. However, if the time of irradiation was prolonged in this solvent, photodimers of carbostyrils could be isolated in high yield. The structure of these dimers is not known with certainty, but we suppose they are analogous to those from carbostyril and $N$-methylcarbostyril. ${ }^{7}$ Only when $\mathrm{X}^{1}=\mathrm{X}^{2}=\mathrm{H}$ was photodimerization observed. The results of these photolyses are also summarized in Table 1.

The photolyses of quinoline $N$-oxides in aprotic non-polar solvents have been studied most extensively. In most cases the isomeric carbostyrils (II) could be isolated directly from the photolysis mixtures by concentration and filtration. Preparative layer chromatography (PLC) of the filtrates from the photolysis of Ia, c-e, g, k, l, n, o yielded the $N$-formyl-2-indolinols (IIIa, $\mathrm{c}-\mathrm{e}, \mathrm{g}, \mathrm{k}, \mathrm{l}, \mathrm{n}, \mathrm{o})$. Irradiation of 3 -ethylquinoline $N$-oxide (Ib) in acetone gave 3-ethylcarbostyril and 1-(2-formamidophenyl)-2-butanone (III'b), whereas irradiation of $\mathrm{Ih}, \mathrm{i}, \mathrm{p}$ gave complex reaction mixtures from which only the corresponding carbostyrils (IIh, i, p) were isolated and identified (see, however, the experimental section and Table 1, where all of the presently as well as previously reported ${ }^{2-5,7-9}$ results obtained upon photolysis of type I quinoline $N$-oxides are tabulated). In most of the presently described photolyses small amounts of the parent quinolines and other, unidentified, compounds were observed (Table 1). In some cases $o$-formamidobenzaldehydes were observed as minor products. These are believed to be due to photooxidation of thermal degradation products of the $N$-formyl-2-indolinols (III) or their open-chain tautomers III' ( $f f$. Ref. 10a).

\section{IDENTIFICATION OF PRODUCTS}

The carbostyrils (II), except for 3-ethylcarbostyril (IIb), are all known compounds. They were identified by their melting points and by their characteristic IR, UV, and NMR spectra (Table 2). The photodimers were characterized by their IR and NMR spectra (Table 2) and by their easy thermal conversion to the monomeric carbostyrils. The $N$-formyl-2-indolinols (IIIa, $\mathrm{c}-\mathrm{e}, \mathrm{g}, \mathrm{k}, \mathrm{l}, \mathrm{n}, \mathrm{o}$ ) and the open chain tautomer III'b were identified by comparing their IR and UV spectra with those of the previously described ${ }^{10}$ $N$-acetyl-2-indolinols (Table 3). The NMR-spectra of compounds III and III'b, which are all in excellent agreement with the assigned structures, will be reported separately." The mass spectra of some of the $N$-formyl-2indolinols, which also support the structure assignment, are discussed elsewhere..$^{12}$ 
Table 2. Spectral data and melting

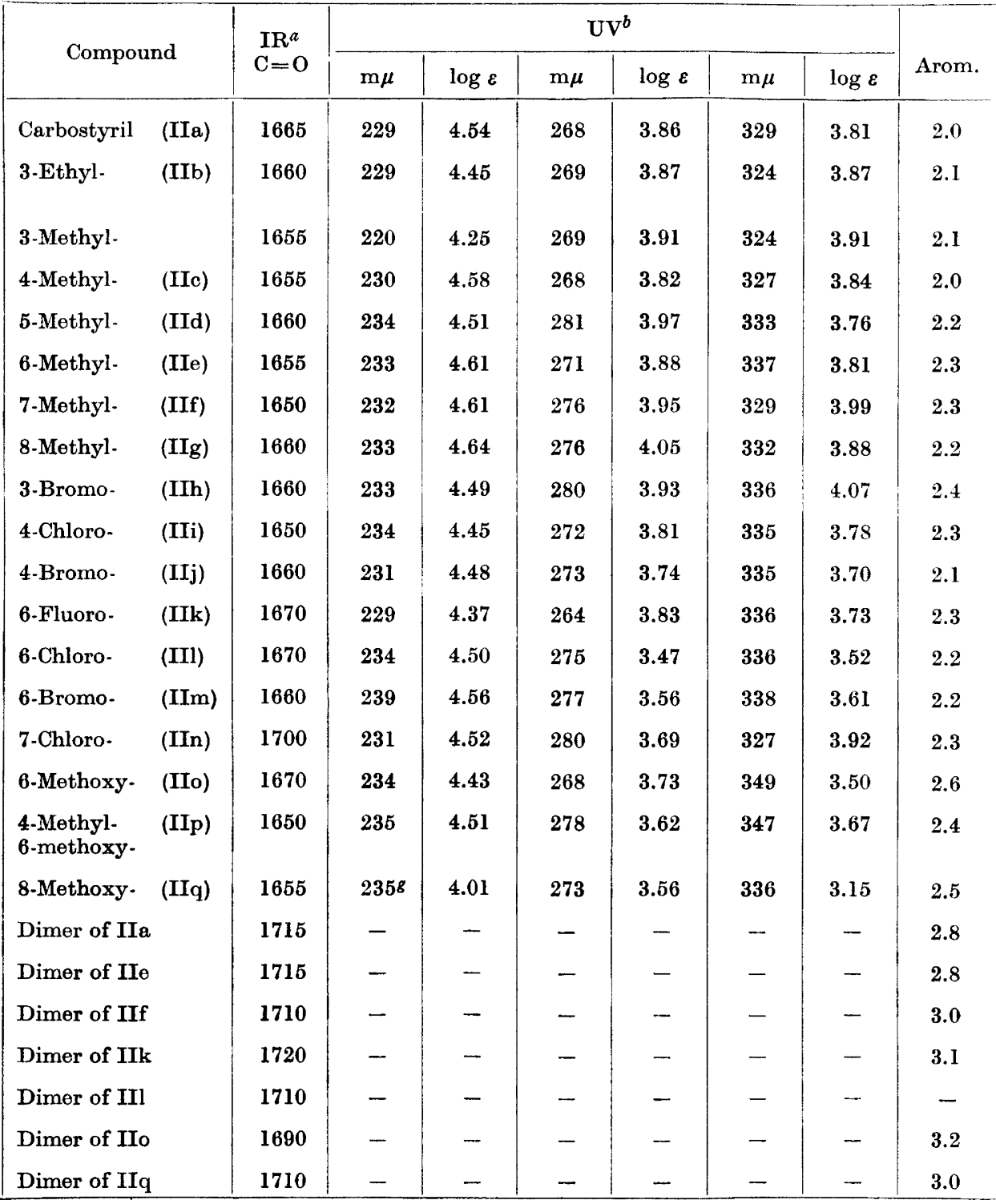

a Spectra recorded in $\mathrm{KBr}$ discs; position reported in $\mathrm{cm}^{-1}$

${ }^{b}$ Spectra recorded in $96 \%$ ethanol.

${ }^{c}$ Spectra recorded in trifluoroacetic acid solution with tetramethylsilane as internal standard. Chemical shifts are reported in $\tau$ units and coupling constants $(J)$ in cps. $s=$ singlet, $d=$ doublet, $\mathbf{t}=$ triplet, and $\mathrm{q}=$ quartet.

$d$ Reference in parentheses.

e Calc. for $\mathrm{C}_{11} \mathrm{H}_{11} \mathrm{NO}$ : $\mathrm{C} 76.27 ; \mathrm{H} \mathrm{6.40;} \mathrm{N} 8.09$. Found: $\mathrm{C} 76.15 ; \mathrm{H} 6.51 ; \mathrm{N} 8.16$.

$f$ Calc. for $\mathrm{C}_{9} \mathrm{H}_{8} \mathrm{NOF}$ : $\mathrm{C} 66.25 ; \mathrm{H} \mathrm{3.71;} \mathrm{N} 8.59$. Found: $\mathrm{C} 66.49 ; \mathrm{H} 4.06$; $\mathrm{N} 8.59$. 
points for carbostyrils and dimers.

\begin{tabular}{|c|c|c|c|c|c|}
\hline \multicolumn{4}{|c|}{$\mathrm{NMR}^{c}$} & \multicolumn{2}{|c|}{ Melting point $\left({ }^{\circ} \mathrm{C}\right)$} \\
\hline $\mathrm{H}(3)$ & $\mathrm{H}(4)$ & Other & Ratio & Obs. & Lit. ${ }^{d}$ \\
\hline $2.55(\mathrm{~d}), J=9$ & $1.23(\mathrm{~d}), J=9$ & - & $4: 1: 1$ & $192-193$ & $192-193(4)$ \\
\hline- & $1.48(\mathrm{~s})$ & $\begin{array}{l}\mathrm{CH}_{3}, 8.53(\mathrm{t}) \\
\mathrm{CH}_{2}, 7.00(\mathrm{q})\end{array}$ & $4: 1: 3: 2$ & $173-174^{e}$ & - \\
\hline - & $1.50(\mathrm{~s})$ & $\mathrm{CH}_{3}, 7.45(\mathrm{~s})$ & $4: 1: 3$ & $238-239$ & $235(18)$ \\
\hline $2.67(\mathrm{~s})$ & - & $\mathrm{CH}_{3}, 7.03(\mathrm{~s})$ & $4: 1: 3$ & $221-222$ & $222-224(19)$ \\
\hline $2.65(\mathrm{~d}), J=9$ & $1.13(\mathrm{~d}), J=9$ & $\mathrm{CH}_{3}, 7.22(\mathrm{~s})$ & $3: 1: 1: 3$ & $227-228$ & $228(20)$ \\
\hline $2.60(\mathrm{~d}), J=9$ & $1.33(\mathrm{~d}), J=9$ & $\mathrm{CH}_{3}, 7.37(\mathrm{~s})$ & $3: 1: 1: 3$ & $236-238$ & $237(21)$ \\
\hline $2.75(\mathrm{~d}), J=9$ & $1.43(\mathrm{~d}), J=9$ & $\mathrm{CH}_{3}, 7.37(8)$ & $3: 1: 1: 3$ & $198-199$ & $198(22)$ \\
\hline $2.63(\mathrm{~d}), J=9$ & $1.37(\mathrm{~d}), J=9$ & $\mathrm{CH}_{3}, 7.22(\mathrm{~s})$ & $3: 1: 1: 3$ & $221-222$ & $218-219(23)$ \\
\hline- & $1.45(\mathrm{~s})$ & - & $4: 1$ & $259-261$ & $253(24)$ \\
\hline $2.72(\mathrm{~s})$ & - & - & $4: 1$ & $249-250$ & $245-247(25)$ \\
\hline $2.53(\mathrm{~s})$ & - & - & $4: 1$ & $261-263$ & $265(26)$ \\
\hline $2.82(\mathrm{~d}), J=9$ & $1.63(\mathrm{~d}), J=9$ & - & $3: 1: 1$ & $268-271 f$ & - \\
\hline $2.73(\mathrm{~d}), J=9$ & $1.58(\mathrm{~d}), J=9$ & - & $3: 1: 1$ & $266-267$ & $267(27)$ \\
\hline $2.80(\mathrm{~d}), J=9$ & $1.63(\mathrm{~d}), J=9$ & - & $3: 1: 1$ & $269-271$ & $268-269(28)$ \\
\hline $2.83(\mathrm{~d}), J=9$ & $1.57(\mathrm{~d}), J=9$ & $\ldots$ & $3: 1: 1$ & $285-287$ & $287-292(29)$ \\
\hline $3.17(\mathrm{~d}), J=9$ & $1.52(\mathrm{~d}), J=9$ & $\mathrm{CH}_{3} \mathrm{O}, 6.02(\mathrm{~s})$ & $3: 1: 1: 3$ & $219-220$ & $215-217(5)$ \\
\hline $2.87(\mathrm{~s})$ & - & $\begin{array}{l}\mathrm{CH}_{3} \mathrm{O}, 5.97(\mathrm{~s}) \\
\mathrm{CH}_{3}, 7.15(\mathrm{~s})\end{array}$ & $3: 1: 3: 3$ & $272-273$ & $268-270(30)$ \\
\hline $2.70(d), J=9$ & $1.45(\mathrm{~d}), J=9$ & $\mathrm{CH}_{3} \mathrm{O}, 5.87(\mathrm{~s})$ & $3: 1: 1: 3$ & $102-103$ & $105(22)$ \\
\hline \multicolumn{2}{|c|}{$5.88(\mathrm{~s})$} & - & $2: 1$ & ca $300^{h, i}$ & - \\
\hline \multicolumn{2}{|c|}{$5.95(\mathrm{~s})$} & $\mathrm{CH}_{3}, 7.70(\mathrm{~s})$ & $3: 2: 3$ & $>300^{h, j}$ & - \\
\hline \multicolumn{2}{|c|}{$5.92(\mathrm{~s})$} & $\mathrm{CH}_{3}, 7.62(\mathrm{~s})$ & $3: 2: 3$ & $>275^{h, k}$ & - \\
\hline \multicolumn{2}{|c|}{$5.93(\mathrm{~s})$} & - & $3: 2$ & $307-312^{h, l}$ & - \\
\hline \multicolumn{2}{|c|}{-} & - & - & $335-350^{h}$ & - \\
\hline \multicolumn{2}{|c|}{$5.92(\mathrm{~s})$} & $\mathrm{CH}_{3} \mathrm{O}, 6.10(\mathrm{~s})$ & $3: 2: 3$ & $267-270^{h}$ & $268-269(5)$ \\
\hline \multicolumn{2}{|c|}{$5.93(\mathrm{~s})$} & $\mathrm{CH}_{3} \mathrm{O}, 6.05(\mathrm{~s})$ & $3: 2: 3$ & $260-261^{h, m}$ & - \\
\hline
\end{tabular}

$g$ This spectrum shows an additional band at $256 \mathrm{~m} \mu(\log \varepsilon=4.04)$.

$h$ Sublimes.

$i$ Calc. for $\mathrm{C}_{18} \mathrm{H}_{14} \mathrm{~N}_{2} \mathrm{O}_{2}$ : C 74.47; $\mathrm{H} 4.86 ; \mathrm{N} 9.65$. Found: C 73.45; H 4.97; $\mathrm{N} 9.42$.

$j$ Calc. for $\mathrm{C}_{20} \mathrm{H}_{18} \mathrm{~N}_{2} \mathrm{O}_{2}$ : C 75.45; $\mathrm{H} 5.70 ; \mathrm{N} \mathrm{8.80}$. Found: $\mathrm{C} 75.12 ; \mathrm{H} \mathrm{5.70;} \mathrm{N} 8.80$.

${ }^{k}$ Calc. for $\mathrm{C}_{20} \mathrm{H}_{18} \mathrm{~N}_{2} \mathrm{O}_{2}$ : C 75.45; $\mathrm{H} 5.70 ; \mathrm{N} 8.80$. Found: $\mathrm{C} 75.52 ; \mathrm{H} 5.49 ; \mathrm{N} 8.82$.

$l$ Calc. for $\mathrm{C}_{18} \mathrm{H}_{12} \mathrm{~N}_{2} \mathrm{O}_{2} \mathrm{~F}_{2}$ : C 66.25; $\mathrm{H} \mathrm{3.71;} \mathrm{N} 8.59$. Found: $\mathrm{C} 65.51 ; \mathrm{H} \mathrm{4.08;} \mathrm{N} 8.31$.

${ }^{m}$ Calc. for $\mathrm{C}_{20} \mathrm{H}_{18} \mathrm{~N}_{2} \mathrm{O}_{4}$ : C 68.56; $\mathrm{H} 5.18 ; \mathrm{N} 8.00$. Found: $\mathrm{C} 68.00 ; \mathrm{H} \mathrm{5.22;} \mathrm{N} 8.08$. 
Table 3. Infrared and ultraviolet spectra of $N$-formyl-2-indolinols (III) and the open-chain tautomer III'b.

\begin{tabular}{|c|c|c|c|c|c|c|c|c|}
\hline & \multicolumn{2}{|c|}{$\mathrm{IR}(\mathrm{KBr}), \mathrm{cm}^{-1}$} & \multicolumn{6}{|c|}{ UV (96\% Ethanol) } \\
\hline & $\mathrm{OH}$ & $\mathrm{C}=\mathrm{O}$ & $\mathrm{m} \mu$ & $\log \varepsilon$ & $\mathrm{m} \mu$ & $\log \varepsilon$ & $\mathbf{m} \mu$ & $\log$ \\
\hline IIIa & 3215 & 1665 & 248 & 4.13 & 278 & 3.61 & 287 & 3.60 \\
\hline IIIc & 3260 & 1680 & $-a$ & - & - & - & - & - \\
\hline IIIIe & 3210 & 1670 & 253 & 4.16 & 286 & 3.58 & 293 & 3.58 \\
\hline IIIg & 3250 & 1660 & 249 & 4.05 & 281 & 3.45 & 302 & 3.28 \\
\hline IIII & 3200 & 1675 & 251 & 3.94 & 288 & 3.07 & 295 & 3.01 \\
\hline IIIk & 3260 & 1670 & 250 & 3.90 & 287 & 3.33 & 294 & 3.28 \\
\hline IIIm & 3280 & 1670 & 260 & 4.18 & 288 & 3.58 & 296 & 3.54 \\
\hline IIIn & 3300 & 1660 & 250 & 3.97 & 288 & 3.37 & 295 & 3.41 \\
\hline IIIo & 3355 & 1675 & 257 & 4.12 & 294 & 3.58 & 303 & 3.51 \\
\hline III'b & - & $\begin{array}{l}1720 \\
1670\end{array}$ & 250 & 4.07 & 279 & 3.53 & 288 & 3.48 \\
\hline
\end{tabular}

${ }^{a}$ See footnote $e$, Table 1 .

\section{DISCUSSION}

The presence of oxygen seems to accentuate the formation of the parent amines in photolyses of quinoline $N$-oxides ${ }^{5}$ and other aromatic amine $N$ oxides. ${ }^{1}$ This fact suggests that the loss of oxygen from the amine oxide proceeds via a singlet excited state.* The other photoproducts probably arise from a triplet excited state.

Although an oxaziridine (IV) has neither been isolated nor observed as a transient intermediate in any of the aromatic amine $N$-oxide photolyses, it is very attractive to regard oxaziridine formation as the primary step in

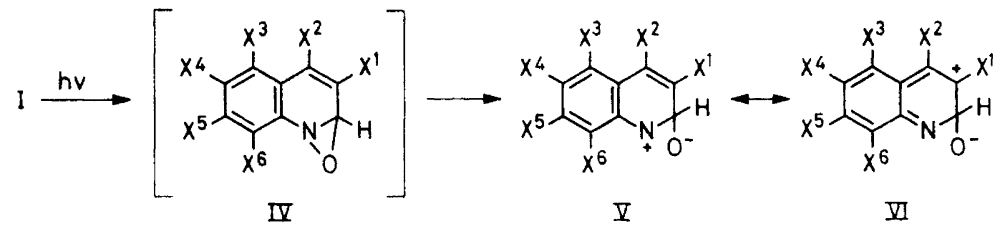

most of these photolyses., ${ }^{1,6,14}$ We have previously suggested (see, e.g., Ref. 14) the heterolysis of the intermediate oxaziridine to produce the zwitterion $\mathrm{V}$-VI. This zwitterion can rearrange to a carbostyril derivative by either of the two intramolecular paths shown below.

We fully realize the possibility of other reaction paths (perhaps intermolecular) leading from the zwitterion V-VI to the carbostyril II and plan to investigate the fate of the proton in the 2-position of quinoline $N$-oxide during photolysis by deuterium labelling.

* For a discussion of triplet and singlet quenching by oxygen see, e.g. Ref. 13. 


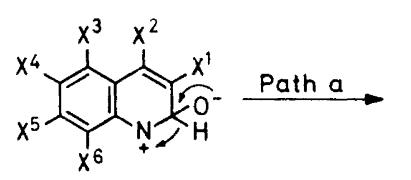

I<smiles>CC(C)(C)C</smiles><smiles>[Y]c1nc2c([R])c([Y])c([Y])c([Y])c2c([Y])c1[Y]</smiles>

पI<smiles>[Y]c1[Y]([H])c2c([Y])c([Y])c(=O)[nH]c2c([Y])c1[Y]</smiles>

II<smiles>C[12CH3]</smiles><smiles>[Y]c1c([Y])c([Y])c2c([Y4])c([Y4])c(=O)[nH]c2c1[Y]</smiles>

III

In the photolysis of a series of 2-methylquinoline $N$-oxides in aprotic solvents we observed ${ }^{10 a}$ only a $\mathrm{C}(2)$ to $\mathrm{C}(3)$ shift (analogous to path $b$ ) and no $N$-methylcarbostyril was detected in the photolysis of an aqueous solution of 2-methylquinoline $N$-oxide. ${ }^{10 b}$ However, it has been reported ${ }^{5}$ that 2methyl- and 2,4-dimethylquinoline $N$-oxides rearrange to the corresponding $N$-methylcarbostyrils (analogously to path $a$ ) upon photolysis in methanol. Part of the reason for these somewhat contradictory results may be the influence of the different solvents used, but it is possible that both pathways can occur simultaneously.

The formation of the isomeric benz[d][1,3]oxazepines (VIII) from the zwitterions V-VI and the conversion of these seven-membered rings to the<smiles>[Y]c1nc2c([Y4])c([Y])c([Y])c([Y4])c2c([Y4])c1[Y4]</smiles>

III

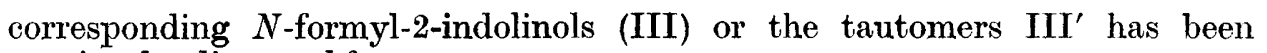
previously discussed. ${ }^{6}$

It is possible that the oxaziridines (IV) undergo homolytic $\mathrm{N}-\mathrm{O}$ bond cleavage, instead of the heterolytic cleavage that we have represented. If the cleavage takes place homolytically the resulting species should undergo some typical radical reactions. Preliminary experiments indicate that photolysis of quinoline $N$-oxides using cyclohexene as the solvent leads to no products incorporating the olefin. These results favor heterolytic cleavage.

The results obtained thus far show that the photolyses of quinoline $N$ oxides are subject to a pronounced solvent effect. This solvent dependence appears to be a general phenomenon; polar, protic media favor carbostyril formation and non-polar, aprotic media favor the production of benz[d][1,3]oxazepines (VIII) or their solvolysis products, the $N$-formyl-2-indolinols (III) or the tautomers III'. 
Finally, we would like to emphasize that the stability of the benz[d][1,3]oxazepines seems to be dependent on the presence of electron-withdrawing substituents in the seven-membered ring.

The only benz[d][1,3]oxazepines thus far reported which are stable enough to be isolated and characterized are 2 -cyano ${ }^{6}$ and 2-phenyl ${ }^{6}$ derivatives.

\section{EXPERIMENTAL}

Microanalyses were carried out in the microanalysis department of this laboratory by Mr. Preben Hansen and his staff.

Melting points (uncorrected) were determined on a Reichert melting point microscope. Infrared spectra were recorded either on a Perkin Elmer "Infracord" or on a Perkin Elmer model 337 spectrophotometer. Ultraviolet spectra were recorded on a Perkin Elmer model 137 UV spectrophotometer. Nuclear magnetic resonance spectra were recorded on a Varian A60A or on a Varian HA 100 spectrometer.

Thin layer chromatograms ( $T L C)$. These were run on $8 \times 10 \mathrm{~cm}$ plates with a $0.25 \mathrm{~mm}$ layer of silica gel $\left(\mathrm{HF}_{254}\right.$, Merck) or aluminium oxide ( $\mathrm{PF}_{254+366}$, Merck). The plates were visualized under UV light.

Preparative layer chromatography $(P L C)$. The method described by Halpaap ${ }^{15}$ was employed. The plates were $40 \times 100 \mathrm{~cm}$. They were developed $2-5$ times with the appropriate solvent and the fractions separated were extracted using a Soxhlet apparatus.

Quinoline $\mathrm{N}$-oxides. All of the quinoline $N$-oxides, except 4-chloroquinoline $N$-oxide, were prepared by oxidation of the corresponding quinolines using the previously described method. 4 -Chloroquinoline $N$-oxide was prepared from 4 -nitroquinoline $N$-oxide by the reported method. ${ }^{16}$

Irradiations. The results are summarized in Table 1. All irradiations were performed through a Pyrex filter. The light source was either a Hanau Q-700 lamp or the $3600 \AA$ lamps of a Rayonet reactor (Type RS). The irradiations were monitored by TLC and continued until no more starting material could be detected. All of the irradiations were carried out by one of the three methods described in detail below.

N-Formyl-2-indolinols. The melting points and analytical data for these compounds are summarized in Table 4.

Table 4. Physical constants and analytical data for $N$-formyl-2-indolinols (III) and the open-chain tautomer III'b.

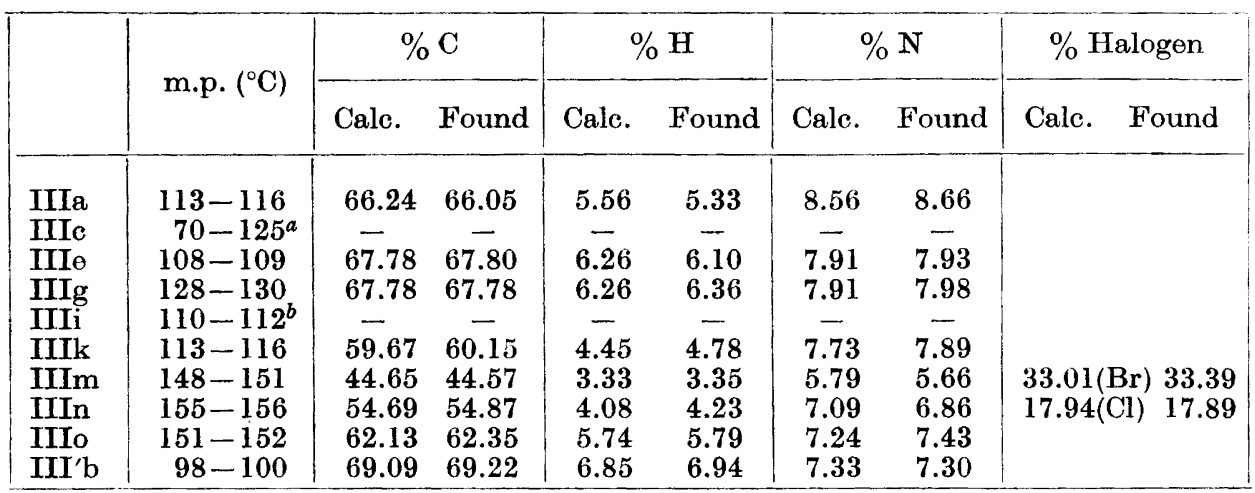

${ }^{a}$ See footnote $e$, Table $1 .{ }^{b}$ See footnote $g$, Table 1 . 
Photolysis of 4-methyl-6-methoxyquinoline N-oxide in water. A $200 \mathrm{mg}$ sample of 4methyl-6-methoxyquinoline $N$-oxide (Ip) was dissolved in $20 \mathrm{ml}$ of water in a Pyrex test tube. The test tube was irradiated by placing it $c a .30 \mathrm{~cm}$ from a Hanau Q-700 lamp equipped with a reflector. After $20 \mathrm{~h}$ of irradiation all starting material was gone (TLC) and colorless crystals were present. Filtration of the mixture gave 4-methyl-6methoxycarbostyril (IIp) as colorless needles $(170 \mathrm{mg}, 85 \%), \mathrm{m} . \mathrm{p} .272-273^{\circ}$.

Photolysis of 6-chloroquinoline $\mathrm{N}$-oxide in ethanol. A $1.00 \mathrm{~g}$ sample of 6-chloroquinoline $N$-oxide (Il) was dissolved in $100 \mathrm{ml}$ of $96 \%$ ethanol and irradiated in Pyrex test tubes ca. $15 \mathrm{~cm}$ from the Hanau Q-700 lamp described above. After ca. $100 \mathrm{~h}$ irradiation the deposited dimer of 6-chlorocarbostyril was isolated by filtration as colorless crystals $(700 \mathrm{mg}, 70 \%)$, m.p. $335-350^{\circ}$ with sublimation. Sublimation of the dimer and recrystallization of the sublimate from ethanol gave 6 -chlorocarbostyril (IIl), m.p. $269-270^{\circ}$.

Photolysis of 6-fluoroquinoline $\mathrm{N}$-oxide in acetone. A $1.50 \mathrm{~g}$ sample of 6 -fluoroquinoline $N$-oxide (Ik) was dissolved in $320 \mathrm{ml}$ of acetone containing a small amount of water and irradiated with a Hanau Q-700 lamp contained in a Pyrex immersion well. After $3 \mathrm{~h}$ of irradiation no more starting material could be detected by TLC. Filtration of the solution gave the dimer of 6-fluorocarbostyril (126 mg, $4 \%$ ), which could be recrystallized from dimethylformamide to give colorless crystals, m.p. 307-312 ${ }^{\circ}$ Sublimation of the dimer and recrystallization of the sublimate from ethanol gave 6-fluorocarbostyril (IIk), m.p. $268-271^{\circ}$.

The filtrate from the dimer was concentrated to a volume of $c a .50 \mathrm{ml}$ and cooled in a dry ice-acetone bath. Filtration of the solution gave 6-fluorocarbostyril (IIk) as colorless crystals $(243 \mathrm{mg}, 16 \%$ ), m.p. 268-271 . An additional $195 \mathrm{mg}$ of 6-fluorocarbostyril was isolated by PLC (see below), making the total yield of 6-fluorocarbostyril $439 \mathrm{mg}(29 \%)$.

The filtrate from the carbostyril was separated by PLC on silica gel using petroleum ether-benzene-acetone (7:7:1 by volume) as the eluent. From the PLC five fractions were isolated.

Fraction A: Colorless oil, $24 \mathrm{mg}$, unidentified.

Fraction B: Colorless oil identified as 6-fluoroquinoline $(66 \mathrm{mg}, 5 \%)$ by IR, UV, and TLC comparison with an authentic sample.

Fraction C: White solid, m.p. $109-115^{\circ}$, which was recrystallized from benzenecyclohexane to give $N$-formyl-5-fluoro-2-indolinol (IIIk) as colorless needles (754 $\mathrm{mg}$, $45 \%$ ), m.p. $113-115^{\circ}$.

Fraction D: Tan solid, m.p. $263-267^{\circ}$, which was recrystallized from ethanol to give 6-fluorocarbostyril (IIk) as colorless needles (195 mg, $13 \%$ ), m.p. $268-271^{\circ}$.

Fraction E: Brown gum, $37 \mathrm{mg}$, unidentified.

Acknowledgement. The authors wish to acknowledge the support of the North Atlantic Treaty Organization in the form of a N.A.T.O. Postdoctoral Research Fellowship to one of the authors (P.L.K.). We also wish to thank the Carlsberg Foundation for a grant used to purchase the Rayonet reactor.

\section{REFERENCES}

1. Buchardt, O. Tetrahedron Letters 19681911.

2. Buchardt, O. and Lohse, C. Tetrahedron Letters 19664355.

3. Streith, J., Darrah, H. K. and Weil, M. Tetrahedron Letters 19665555.

4. Buchardt, O., Becher, J. and Lohse, C. Acta Chem. Scand. 19 (1965) 1120.

5. Ishikawa, M., Yamada, S., Hotta, H. and Kaneko, C. Chern. Pharm. Bull. (Tokyo) 14 (1966) 1102.

6. Buchardt, O., Jensen, B. and Kjøller Larsen, I. Acta Chem. Scand. 21 (1967) 1841.

7. Buchardt, O. Acta Chem. Scand. 18 (1964) 1389.

8. Kaneko, C., Yokoe, I. and Yamada, S. Tetrahedron Letters 1967775.

9. Kamiya, S. Chem. Pharm. Bull. (Tokyo) 10 (1962) 471.

10. a. Buchardt, O., Becher, J. and Lohse, C. Acta Chem. Scand. 20 (1966) 2467; b. Buchardt, O., Becher, J., Lohse, C. and Møller, J. Acta Chem. Scand. 20 (1966) 262.

11. Buchardt, O., Kumler, P. L. and Lohse, C. Acta Chem. Scand. 23 (1969). In press.

Acta Chem. Scand. 23 (1969) No. 1 
12. Buchardt, O., Duffield, A. M. and Djerassi, C. Acta Chem. Scand. 22 (1968) 2329.

13. Calvert, J. G. and Pitts, Jr., J. N. Photochemistry, Wiley, New York 1966, pp. 598600 .

14. Buchardt, O. and Jensen, B. Acta Chem. Scand. 22 (1968) 877.

15. Halpaap, H. Chem..Ing..Tech. 35 (1963) 488.

16. Okamoto, T. J. Pharm. Soc. Japan 71 (1951) 297.

17. Buchardt, O. Acta Chem. Scand. 17 (1963) 1461.

18. Cunningham, K. G., Newbold, G. T., Spring, F. S. and Stark, J. J. Chem. Soc. 1949 2091.

19. Lauer, W. M. and Kaslow, C. E. Org. Syn. Coll. Vol. 3 (1963) 580.

20. Yoshikawa, T. Yakugaku Zasshi 81 (1961) 1601.

21. Colonge, J. and Chambard, R. Bull. Soc. Chim. France. 1953982.

22. Sidhu, G. S., Thyagarajan, G. and Ansari, S. Ann. 627 (1959) 218.

23. Case, F. H. and Lafferty, J. J. J. Org. Chem. 23 (1958) 1.375.

24. Decker, H. J. prakt. Chem. 45 (1892) 47.

25. Hamana, M. J. Pharm. Soc. Japan 75 (1955) 127.

26. Hamana, M., Hoshide, Y. and Kaneda, K. J. Pharm. Soc. Japan 76 (1956) 1337.

27. Bachman, G. B. and Cooper, D. E. J. Org. Chem. 9 (1944) 302.

28. Uyeda, H. J. Chem. Soc. Japan 65 (1944) 200.

29. Lutz, R. E., Ashburn, G. and Rowlett, R. J. J. Am. Chem. Soc. 68 (1946) 1322.

30. Monti, L. and Cirelli, V. Gazz. Chim. Ital. 66 (1936) 723.

Received May 15, 1968. 